\title{
Philosophy of ecology of Justus von Liebig: different Liebig
}

\author{
Alexander A. Nikolskii, Elena A. Vanisova \\ Peoples' Friendship University of Russia (RUDN University) \\ 6 Miklukho-Maklaya St, Moscow, 117198, Russian Federation
}

\begin{abstract}
German chemist Justus von Liebig is known in the ecological literature as the author of "Liebig's law of the minimum". But the law of the minimum is absent in his publications, which ecologists cite. The "law" is nothing more than an interpretation of some of Liebig's statements. However, irrespective of the law of the minimum, Liebig's outstanding contribution to the theory of ecology is obvious: Liebig was one of the first who drew attention to the sustainability of the phenomenon of life organized into supraorganismal systems. Liebig showed that as a result of the interaction of plants and animals and as a result of their life processes, such as nutrition and respiration, there is a continuous transformation of a substance consisting of the same elements. On the example of the constancy of the gas composition of the atmosphere, Liebig comes to a generalization that is crucial for ecology: the interaction of plants and animals is a factor of sustainability of their own environment, which they create themselves and support for an unlimited time in a stable state.
\end{abstract}

Keywords: Justus von Liebig, philosophy of ecology, sustainability of the phenomenon of life, law of the minimum

The name of the eminent German chemist Justus von Liebig went into ecological literature as the author of the so-called "Liebig's law of the minimum". In fact, Liebig did not formulate any law of the minimum, what was noted almost 100 years ago by the famous agricultural chemist D.N. Pryanishnikov [1]. Sometimes, even in authoritative ecology manuals, Liebig is credited with some facts that he, in principle, could not speak. For example, I.A. Shilov [2. P. 224] writes in the repeatedly reprinted textbook on ecology for universities: "Back in the middle of the XIX century, the famous German chemist J. Liebig... formulated the rule of the minimum (italics are by I. Shilov), according to which the possibility of the existence of given species in a certain area and the degree of its "prosperity" depend on factors presented in the least amount". Liebig, on the basis of his theory of chemical nutrition of plants, gave practical recommendations to rural owners on how to use fertilizers properly. And, of course, he could not consider "the possibility of the existence of given species", especially "in a certain area".

(C) Nikolskii A.A., Vanisova E.A., 2020

(c) (i) This work is licensed under a Creative Commons Attribution 4.0 International License https://creativecommons.org/licenses/by/4.0/ 
This was not within the scope of his scientific interests and his competence. Examples of free interpretation of Liebig's works can be found in many study guides.

The invented law of the minimum stems from Liebig's remarks that the substances needed by plants, even those required in a minimal amount, affect the crop and must be present in the soil where plants grow [3; 4]. Nevertheless, the myth of the law of the minimum has played a prominent role in the development of the concept of limiting factors, which has become a key idea in modern ecology [5; 6].

The goal of our work is to pay attention to the brilliant prevision of Liebig the ecologist: for many decades ahead of its time, Liebig in fact created the theory of the stability of the life phenomenon, organized into supraorganismal system. And this despite the fact that in his time it was absent not only the concept of "sustainability" in the context of the currently popular sustainable development, but almost all the basic notions of modern ecology, such as tolerance, trophic levels, biosphere, food chains, ecosystem, ecological niche, etc. [6]. Ecology as an independent science [7] appeared 25 years, and the concept of "ecosystem" [8] 100 years before the publication of the main work of Liebig [1], in which he discusses the transformation processes of matter in ecosystems.

In 1837, the young Liebig made a report in The British Association for the Advancement of Science, and the first edition of his famous book "Organic chemistry in its applications to agriculture and physiology" was published in 1840 in English [3] and German [9]. In 1864 the book was published in Russian [10]. To Russian-speaking readers, it is known mainly from the Soviet edition of 1936 [11]. This edition is accompanied by an excellent commentary and an introductory article by academician D.N. Pryanishnikov [1], one of the leading agrochemists of the first half of the $20^{\text {th }}$ century.

In "Organic chemistry", Liebig develops a chemical theory of plant nutrition and, relying on it, makes recommendations to farmers regarding the use of mineral fertilizers to increase agricultural crop yields.

In the Introduction, Liebig outlined the main purpose of his work [3. P. 2]: "The purport of this work is to elucidate the chemical processes engaged in the nutrition of vegetables".

In the first part, which he called "The chemical processes in the nutrition of vegetables", Liebig develops the concept of sustainability as a result of life activity and interaction of organisms. First of all, he draws attention to the constancy of the gas composition in the atmosphere, repeatedly emphasizing that this constancy is the result of the interaction of plants and animals, as well as the result of the vital activity of organisms.

Liebig was greatly impressed by the undeniable fact of a constant (21 percent), over a long time, oxygen content in the Earth's atmosphere. He writes [3. P. 16]: "... at every period and in every climate, to contain 21 volumes of oxygen, with such small deviations, that they must be ascribed to errors of observation". And then he gives a spectacular image - Pompeii's air contained the same 21 percent of oxygen [3. P. 17]: "...the air at the present day, for example, does not contain less oxygen than that found in jars buried for 1800 years in Pompeii...".

The key generalization by Liebig in the context of the air composition constancy consists in the fact that the interaction of animals and plants is not just a factor 
of stability but the factor of sustainability of the environment in which they live and which they create themselves and support for an unlimited time in a stable state [3. P. 21]: "Plants not only afford the means of nutrition for the growth and continuance of animal organization, but they likewise furnish that which is essential for the support of the important vital process of respiration; for besides separating all noxious matters from the atmosphere, they are an inexhaustible source of pure oxygen, which supplies the loss which the air is constantly sustaining. Animals on the other hand expire carbon, which plants inspire; and thus the composition of the medium in which both exist (italics are ours. - A.N., E.V.), namely, the atmosphere, is maintained constantly unchanged".

Considering the conceptual apparatus of that time, it is obvious that Liebig comes to a conclusion that is fundamental for modern ecology: the stability of the phenomenon of life is possible due to its organization into supraorganismal systems (ecosystems), and it is the result of organisms' interaction and of their vital activity.

Developing the idea of the stability of the atmospheric gas composition as a factor of vital activity and the interaction of organisms, Liebig goes on to a broader generalization to the level of the global ecological system - the biosphere [3. Pp. 23-24]: "The proper, constant, and inexhaustible sources of oxygen gas are the tropics and warm climates, where a sky, seldom clouded, permits the glowing rays of the sun to shine upon immeasurably luxuriant vegetation. The temperate and cold zones, where artificial warmth must replace deficient heat of the sun, produce, on the contrary, carbonic acid in superabundance, which is expended in the nutrition of the tropical plants. The same stream of air, which moves by the revolution of the earth from the equator to the poles, brings to us, in its passage from the equator, the oxygen generated there, and carries away the carbonic acid formed during our winter".

Liebig reasoning about the remarkable phenomenon of air transfer, due to which the continuous vegetation of plants near the equator makes it possible to live in temperate and high latitudes all year round, keeping steady the gas composition of the atmosphere as the habitat of plants and animals created by the plants and animals themselves.

At present, the phenomenon of the dependence of life in high latitudes on what happens near the equator is recognized by the international community as a sociopolitical problem that obliges states with different levels of development to the closest and most fruitful cooperation to achieve the goals of maintaining a sustainable state of the biosphere as a habitat. Examples of such cooperation are, in particular, the Convention on Biological Diversity and the Resolution adopted by the General Assembly of the United Nations for Sustainable Development.

The first and it seems the only ones who drew attention to the broad views of Liebig as an ecologist were V.D. Fedorov and T.G. Gilmanov. In their opinion [12. Pp. 49-50], "Justus Liebig's ideas were completely consonant with modern ideas of a systems approach. J. Liebig accentuated that there is a natural connection between all phenomena in the mineral, plant and animal kingdoms that determine the existence of life on the earth's surface, so that none of phenomena does exist by itself, in isolation, but always in connection with one or more other events, which in turn are in the chain of other phenomena". 
Relatively recently P. Larry Phelan [13], criticizing Liebig for his reductionism, however, in emotional terms ("von Liebig set in motion a train") noticed that Liebig's ecological views were ignored [13. P. 100]: "Nevertheless, von Liebig set in motion a train that even he could not slow, and his later more balanced (one might even say more ecological) views on plant nutrition have been largely ignored for his earlier strictly chemical ones". It is noteworthy that this is published in a collective monograph called "Sustainable Agroecosystem Management: Integrating Ecology, Economics and Society”.

Exploring "the chemical processes engagedin the nutrition of vegetables", Liebig arrived at a fundamental generalization known in modern ecology as the constellation of ecological factors, that is their joint action. In "Principles of agricultural chemistry" [4. Pp. 30-31] Liebig says so about it: "The absence or deficiency, or the want of available form, in that one constituent, renders the others which are present ineffectual, or diminishes their efficacy" (italics are by Liebig). The ratio of factors greatly affects the limits of tolerance for each of them, that is one of the most relevant and difficult problems of factorial ecology (for example, $[2 ; 5$; $12 ; 14 ; 15])$. Currently, the problem of constellation is becoming particularly relevant in connection with the increasing influence of anthropogenic factors. A huge amount of literature is devoted to this problem.

The reasonings of Liebig the chemist are surprising in their insight about what we call in the today's ecology "the separation of ecological niches". In the abovementioned "Principles of agricultural chemistry" Liebig comes close to the concepts of "ecological niche" and "competitive exclusion" [4. P. 30]: "Two plants, whose root fibres have an equal length and extent, do not thrive so well beside each other, or in succession, as two whose roots, being of unequal length, receive eheir food from different strata or depths of the soil" (italics are by Liebig). There is a desire to continue Liebig's thought with Hutchinson's reasonings that according to the principle of competitive exclusion [16-19] two species with similar needs "when they co-occur, must in some sense the occupying different niches" [20. P. 417].

And, of course, Liebig's thought many times repeated about the circulation of substances suggests that the idea of sustainability of the life phenomenon organized into supraorganismal systems was the leading concept in his theory of the nutrition of plants [3. P. 161]: "It was evident that all plants must give back to the soil in which they grow different proportions of certain substances, which are capable of being used as food by a succeeding generation".

And in conclusion, we would like to draw attention to the need for a new reading of Liebig's works by ecologists. For ecology, Liebig is not only the "Liebig's barrel", widely distributed on the Web. Liebig's vision of the structure of the organic world takes on special relevance in connection with the actively discussed problem of sustainable development of the Nature - Society system - the problem raised to the level of the United Nations.

\section{References}

[1] Pryanishnikov DN. Razvitie vzglyadov na pitanie rastenii i rol' Libikha v sozdanii sovremennogo ucheniya ob udobrenii [Development of views on plant nutrition and the role of Liebig in creating modern doctrine of fertilizer]. In: Liebig J. Khimiya v pri- 
lozhenii $k$ zemledeliyu i fiziologii [Chemistry in its applications to agriculture and physiology]. Moscow, Leningrad: Sel'hozgiz Publ.; 1936. p. 5-27. (In Russ.)

[2] Shilov IA. Ekologiya [Ecology]: textbook for biological and medical specialties of universities. Moscow: Vysshaya shkola Publ.; 1997. (In Russ.)

[3] Liebig J. Organic chemistry in its applications to agriculture and physiology. London: Taylor and Walton; 1840.

[4] Liebig J. Principles of agricultural chemistry: with special reference to the late researches made in England. New York: John Willey; 1855.

[5] Odum EP. Fundamentals of Ecology. $3^{\text {rd }}$ ed. Philadelphia, London, Toronto: W.B. Saunders Company; 1971.

[6] Nikol'skii AA. Velikie idei velikikh ekologov: istoriya klyuchevykh kontseptsii v ekologii [The great ideas of the great ecologists: history of key concepts in ecology]. Moscow: GEOS Publ.; 2014. (In Russ.)

[7] Haeckel E. Generelle Morphologie der Organismen. Bd. 1, 2. Berlin: Verlag von Georg Reimer; 1866.

[8] Tansley AG. The use and abuse of vegetational concepts and terms. Ecology. 1935; 16(3):284-307.

[9] Liebig J. Die organische Chemie in ihrer Anwendung auf Agricultur und Physiologie. Braunschweig: F. Vieweg und Sohn; 1840.

[10] Liebig J. Khimiya v prilozhenii $k$ zemledeliyu i fiziologii [Chemistry in its applications to agriculture and physiology]. Saint Petersburg: Tipografiya Fridrikha Fivega i syna v Braunshveige; 1864. (In Russ.)

[11] Liebig J. Khimiya v prilozhenii $k$ zemledeliyu i fiziologii [Chemistry in its applications to agriculture and physiology]. Moscow, Leningrad: Sel'hozgiz Publ.; 1936. (In Russ.)

[12] Fedorov VD, Gil'manov TG. Ekologiya [Ecology]. Moscow: Izd-vo Moskovskogo universiteta Publ.; 1980. (In Russ.)

[13] Phelan PL. Ecology-Based Agriculture and the Next Green Revolution. In: Bohler PJ, Houser G. (eds.) Sustainable Agroecosystem Management: Integrating Ecology, Economics and Society. London, New York: CRC Press; 2009. p. 98-136.

[14] Shelford VE. The reactions of certain animals to gradients of evaporating power of air: a study in experimental ecology. Biological bulletin. 1913;25(2):79-120.

[15] Shvarts SS. Teoreticheskie osnovy i printsipy ekologii [Theoretical foundations and principles of ecology]. Sovremennye problemy ekologii: doklady Pyatoi Vsesoyuznoi ekologicheskoi konferentsii [Modern problems of ecology: reports of the Fifth All-Union Environmental Conference]. Moscow: Izd-vo Moskovskogo universiteta Publ.; 1973. p. 21-31. (In Russ.)

[16] Volterra V. Variazioni e fluttuazioni del numerodi' individui in specie animali conviventi. Mem. R. Accad. Naz. Dei Lincei. Ser. VI. 1926;2:3-113.

[17] Lotka AJ. The growth of mixed populations: two species competing for a common food supply. Journ. Wash. Ac. Sci. 1932;22 (2):461-469.

[18] Gause GF. Experimental studies on the struggle for existence. I. Mixed population of two species of yeast. Journ. Exp. Biol. (British). 1932;9:389-402.

[19] Gause GF. The Struggle for Existence. Baltimore: The Williams and Wilkins Company; 1934.

[20] Hutchinson GE. Concluding remarks. Cold Spring Harbor Symposia on Quantitative Biology. 1957;22 (2):415-427.

Article history:

Received: 12.10 .2019

Revised: 20.11.2019

\section{For citation:}

Nikolskii AA, Vanisova EA. Philosophy of ecology of Justus von Liebig: different Liebig. RUDN Journal of Ecology and Life Safety. 2020;28(1):75-81. http://dx.doi.org/10.22363/ 2313-2310-2020-28-1-75-81 


\title{
Bio notes:
}

Alexander A. Nikolskii, Doctor of Biological Sciences, Professor, Professor of the Department of System Ecology of Faculty of Ecology of Peoples' Friendship University of Russia (RUDN University). E-mail: bobak@list.ru

Elena A. Vanisova, $\mathrm{PhD}$ in Biological Sciences, Associate Professor of the Department of System Ecology of Faculty of Ecology of Peoples' Friendship University of Russia (RUDN University). E-mail: vanhelen@mail.ru

DOI 10.22363/2313-2310-2020-28-1-75-81

Обзорная статья

\section{Философия экологии Юстуса Либиха: другой Либих}

\author{
А.А. Никольский, Е.А. Ванисова \\ Российский университет дружбы народов \\ Российская Федерачия, 115093, Москва, Подольское шоссе, д. 8, корп. 5
}

\begin{abstract}
Аннотация. Немецкий химик Юстус Либих известен в экологической литературе как автор “закона минимума Либиха". Но в его публикациях, на которые ссылаются экологи, закон минимума отсутствует. “Закон” представляет собой не что иное, как интерпретацию некоторых высказываний Либиха. Тем не менее безотносительно к закону минимума выдающийся вклад Либиха в теорию экологии очевиден: он был одним из первых, кто обратил внимание на устойчивость феномена жизни, организованного в надорганизменные системы. Либих показал, что в результате взаимодействия растений и животных, а также процессов их жизнедеятельности, таких как питание и дыхание, происходит непрерывное преобразование вещества, состоящего из одних и тех же элементов. На примере постоянства газового состава атмосферы Либих приходит к ключевому для экологии обобщению: взаимодействие растений и животных является фактором устойчивости их собственной среды обитания, которую они сами создают и неограниченно долго поддерживают в устойчивом состоянии.
\end{abstract}

Ключевые слова: Юстус Либих, философия экологии, устойчивость феномена жизни, закон минимума

\section{Список литературы}

[1] Прянишников Д.Н. Развитие взглядов на питание растений и роль Либиха в создании современного учения об удобрении // Либих Ю. Химия в приложении к земледелию и физиологии. М. - Л.: Сельхозгиз, 1936. С. 5-27.

[2] Шилов И.А. Экология: учебник для биол. и мед. спец. вузов. М.: Высшая школа, $1997.512 \mathrm{c}$.

[3] Liebig J. Organic chemistry in its applications to agriculture and physiology. London: Taylor and Walton, 1840. $387 \mathrm{p}$.

[4] Liebig J. Principles of agricultural chemistry: with special reference to the late researches made in England. New York: John Willey, 1855. 105 p.

[5] Odum E.P. Fundamentals of Ecology. $3^{\text {rd }}$ ed. Philadelphia - London - Toronto: W.B. Saunders Company, 1971. 574 p.

[6] Никольский A.A. Великие идеи великих экологов: история ключевых концепций в экологии. М.: ГЕОС, 2014. 190 с. 
[7] Haeckel E. Generelle Morphologie der Organismen. Bd. 1, 2. Berlin: Verlag von Georg Reimer, 1866.

[8] Tansley A.G. The use and abuse of vegetational concepts and terms // Ecology. 1935. Vol. 16. No. 3. Pp. 284-307.

[9] Liebig J. Die organische Chemie in ihrer Anwendung auf Agricultur und Physiologie. Braunschweig: F. Vieweg und Sohn, 1840. 353 p.

[10] Либих Ю. Химия в приложении к земледелию и физиологии. СПб.: Типография Фридриха Фивега и сына в Брауншвейге, 1864. 467 с.

[11] Либих Ю. Химия в приложении к земледелию и физиологии. М. - Л.: Сельхозгиз, 1936. $408 \mathrm{c}$.

[12] Федоров В.Д., Гильманов Т.Г. Экология. М.: Изд-во Моск. ун-та, 1980. 464 с.

[13] Phelan P.L. Ecology-Based Agriculture and the Next Green Revolution // Sustainable Agroecosystem Management: Integrating Ecology, Economics and Society / ed. by P.J. Bohler, G. Houser. London, New York: CRC Press, 2009. Pp. 98-136.

[14] Shelford V.E. The reactions of certain animals to gradients of evaporating power of air: a study in experimental ecology // Biological bulletin. 1913. Vol. 25. No. 2. Pp. 79-120.

[15] Швари C.C. Теоретические основы и принципы экологии // Современные проблемы экологии: доклады Пятой Всесоюзной экологической конференции. М.: Изд-во Московского университета, 1973. С. 21-31.

[16] Volterra $V$. Variazioni e fluttuazioni del numerodi' individui in specie animali conviventi // Mem. R. Accad. Naz. Dei Lincei. Ser. VI. 1926. Vol. 2. Pp. 3-113.

[17] Lotka A.J. The growth of mixed populations: two species competing for a common food supply // Journ. Wash. Ac. Sci. 1932. Vol. 22. No. 2. Pp. 461-469.

[18] Gause G.F. Experimental studies on the struggle for existence. I. Mixed population of two species of yeast // Journ. Exp. Biol. (British). 1932. Vol. 9. Pp. 389-402.

[19] Gause G.F. The Struggle for Existence. Baltimore: The Williams and Wilkins Company, 1934. $163 \mathrm{p}$.

[20] Hutchinson G.E. Concluding remarks // Cold Spring Harbor Symposia on Quantitative Biology. 1957. Vol. 22. No. 2. Pp. 415-427.

\section{История статьи:}

Дата поступления в редакцию: 12.10.2019

Дата принятия к печати: 20.11.2019

\section{Для цитирования:}

Nikolskii A.A., Vanisova E.A. Philosophy of ecology of Justus von Liebig: different Liebig // Вестник Российского университета дружбы народов. Серия: Экология и безопасность жизнедеятельности. 2020. Т. 28. № 1. С. 75-81. http://dx.doi.org/10.22363/2313-2310$2020-28-1-75-81$

\section{Сведения об авторах:}

Никольский Александр Александрович, доктор биологических наук, профессор, профессор кафедры системной экологии экологического факультета Российского университета дружбы народов. E-mail: bobak@list.ru

Ванисова Елена Александровна, кандидат биологических наук, доцент кафедры системной экологии экологического факультета Российского университета дружбы народов. E-mail: Vanisobva-ea@rudn.ru. 